ORIGINAL ARTICLE

ISSN 0103-5150

Fisioter. Mov., Curitiba, v. 33, e003307, 2020

DOI: http://dx.doi.org/10.1590/1980-5918.33.A007

Licensed under a Creative Commons attribution

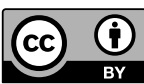

\title{
Sexual function and functioning of women in reproductive age
}

\author{
Função sexual e funcionalidade de mulheres em idade reprodutiva
}

\section{Función sexual y funcionalidad de las mujeres en edad reproductiva}

\author{
Jardelina Hermecina Dantas 맘], Thaissa Hamana de Macedo Dantas (ㅁ] [a], \\ Alianny Raphaely Rodrigues Pereira ${ }^{[b]}$, Grasiela Nascimento Correia $\mathbb{\circledR}^{[a]}$, Luciana Castaneda $\mathbb{C}^{[c]}$, \\ Diego de Sousa Dantas $\left[{ }^{[a, b] *}\right.$
}

[a] Universidade Federal do Rio Grande do Norte (UFRN), Santa Cruz, RN, Brazil

[b] Universidade Federal de Pernambuco (UFPE), Recife, PE, Brazil

[c] Rede Brasileira de Pesquisa em Funcionalidade. Instituto Federal de Educação, Ciência e Tecnologia do Rio de Janeiro (IFRJ), Rio de Janeiro, RJ, Brazil

\section{Abstract}

Introduction: Sexual function (SF) is an important issue in women's health from the beginning of sexual life. SF can be modified by several factors, and the presence of sexual dysfunction may negatively affect the quality of life of these women. Objective: This study aimed to investigate the sexual function, its associated factors and the association with the functioning in women in reproductive age. Method: A cross-sectional observational study with 172 women that attended 6 Family Health Facilities in the northeast region of Brazil. The evaluation tool consisted of (i) sociodemographic, obstetrical and gynecological issues, and questions about habits and health conditions, (ii) female sexual quotient (FSQ), and (iii) World Health Organization Assessment Schedule 2.0 (WHODAS 2.0). Prevalence of sexual dysfunction was calculated, and bivariate analysis was used to estimate the association of independent variables with the outcome of sexual dysfunction. Results: The prevalence of sexual dysfunction was $37.2 \%$, and $39.5 \%$ of the sample considered their sexual health as fair to good. In

* JHD: BS, e-mail: jardelinadantas@gmail.com THMD: Doctoral student, e-mail: thaissa_hamana@hotmail.com ARRP: Master student, e-mail: aliannyrodrigues@hotmail.com GNC: PhD, e-mail: grasiela_n_correia@yahoo.com.br LC: PhD, e-mail: luciana.ribeiro@ifrj.edu.br DSD: PhD, e-mail: diego.sdantas@ufpe.br 
total, $26.2 \%$ of women never think of sex spontaneously, they do not remember or imagine themselves during sexual intercourse, and $38.4 \%$ think about it sometimes. No association was found between the investigated variables and sexual dysfunction; however, the latter showed an association on interpersonal relationships of women $(p=0.016)$. Conclusions: There is a considerable prevalence of sexual dysfunction between women in reproductive age. Thus, results emphasize the relevance of investigations about female sexual function among women in reproductive age that are not in the pregnancy and postpartum period.

Keywords: Women's Health. Epidemiology. Sexual Dysfunction.

\section{Resumo}

Introdução: A função sexual (FS) é uma questão importante na saúde das mulheres a partir do início da vida sexual. A FS pode ser modificada por vários fatores e na presença de disfunção sexual poderá afetar negativamente a qualidade de vida dessas mulheres. Objetivo: investigar a prevalência da disfunção sexual, os fatores associados em mulheres em idade fértil e o impacto dessa disfunção na funcionalidade. Método: Trata-se de um estudo observacional transversal com 172 mulheres atendidas em seis Unidades de Saúde da Família no nordeste do Brasil. A ferramenta de avaliação consistiu em (i) questões sociodemográficas, obstétricas e ginecológicas e perguntas sobre hábitos e condições de saúde, (ii) quociente sexual feminino (QSF) e (iii) World Health Organization Assessment Schedule 2.0 (WHODAS 2.0). A prevalência de disfunção sexual foi calculada e a análise bivariada foi utilizada para estimar a associação de variáveis independentes com o desfecho disfunção sexual. Resultados: A prevalência de disfunção sexual foi de 37,2\%, e 39,5\% da amostra considerou sua saúde sexual como regular ou boa. Desse total, 26,2\% das mulheres nunca costumam pensar espontaneamente em sexo, nem se lembram ou se imaginam durante a relação sexual e 38,4\% pensam apenas às vezes. Não foi encontrada associação entre as variáveis estudadas e a disfunção sexual, porém esta mostrou impacto nas relações interpessoais das mulheres ( $p=0,016)$. Conclusão: Há considerável prevalência de disfunção sexual entre as mulheres com idade reprodutiva. Destaca-se a relevância de investigações acerca da função sexual feminina entre mulheres em idade reprodutiva e que não estejam no ciclo gravídico-puerperal..

Palavras-chave: Saúde da Mulher. Epidemiologia. Disfunções Sexuais Fisiológicas.

\section{Resumen}

Introducción: La función sexual (FS) es un tema importante para la salud de las mujeres desde el comienzo de su vida sexual. La FS puede ser modificada por varios factores, y en presencia de disfunción sexual puede afectar negativamente la calidad de vida de estas mujeres. Objetivo: Investigar la prevalencia de la disfunción sexual, los factores asociados en las mujeres en edad reproductiva y el impacto de esta disfunción en el funcionamiento. Método: Estudio observacional transversal con 172 mujeres que recibían atención en seis Unidades de Salud de la Familia en la región Nordeste de Brasil. La evaluación consistió en: (i) cuestiones sociodemográficas, obstétricas y ginecológicas, preguntas sobre hábitos y condiciones de salud; (ii) cociente sexual femenino; y (iii) WHODAS 2.0. Se calculó la prevalencia de la disfunción sexual y se utilizó el análisis bivariado para estimar la asociación de variables independientes con el resultado de la disfunción sexual. Resultados: La prevalencia de disfunción sexual fue del 37,2\% y el 39,5\% de la muestra consideró su salud sexual como regular o buena. El 26,2\% de las mujeres nunca suelen pensar espontáneamente en el sexo, ni se acuerdan o se imaginan durante la relación sexual y el 38,4\% piensan apenas a veces. No se encontró asociación entre las variables estudiadas y la disfunción sexual, pero ésta mostró impacto en las relaciones interpersonales de las mujeres ( $p=0,016)$. Conclusión: Hay una considerable prevalencia de disfunción sexual entre mujeres en edad reproductiva. Se destaca la relevancia de investigaciones acerca de la función sexual femenina entre mujeres en edad reproductiva y que no estén en el ciclo gravídico-puerperal.

Palabras clave: Salud de la Mujer. Epidemiología. Disfunciones Sexuales Fisiológicas. 


\section{Introduction}

The functional health of individuals is characterized as a state of functioning and both individual and collective well-being, in all life cycles, in the performance of activities and in social participation, promoting quality of life and autonomy for the full exertion of citizenship, and it is exploited to the maximum by motor, intellectual, expressive and relational skills [1].

In this sense, an integral view to the woman focused on functional health should go beyond the puerperal-pregnancy cycle or programmatic family planning actions and address other equally relevant issues in women's lives such as body image, sexual function and mental health [2].

Sexuality is an important component of women's overall quality of life [3], being defined as a complex product of genetic characteristics, experiences, attitudes, behaviors $[4,5]$, cultural and religious aspects associated with gender [6].

As age increases, human life undergoes changes in several aspects and the sexual function is considered one of the issues that undergo such changes [5], which is fundamental for satisfaction and general quality of life [7]. The description of women's sexual function encompasses the behavior of their sexual identity and their sexual intercourses [8].

The female sexual response is divided into phases. The first is represented by sexual desire, characterized by fantasies and willingness to perform sexual activity. In the excitement phase, there is a feeling of sexual pleasure and simultaneous physiological changes, such as vaginal lubrication. The orgasm phase is the apex of sexual pleasure, with a feeling of general well-being and muscle relaxation. Negative changes in these functions are related to sexual dysfunctions, e.g. dyspareunia, orgasmic dysfunction, loss of sexual desire $[6,9,10]$.

Sexual dysfunction is a common problem among women of all ages, negatively affecting not only their quality of life but also the sexual function and quality of life of their partners [11]. Therefore, the World Health Organization (WHO) recognizes sexual dysfunction as a public health problem and recommends its investigation due to the important changes in the quality of life of women caused by this condition [7]. Other conditions, such as urinary incontinence, also affect female sexual function by reducing sexual desire and decreasing intercourse satisfaction, as well as hindering arousal in sexually active women [12].

The International Classification of Functioning, Disability, and Health (ICF) is a classification used worldwide to measure human functioning, and summarized assessment tools, such as WHODAS 2.0, were used [13]. Human functioning encompasses aspects of body functions and structures, activities and participation, as well as personal and environmental factors, also encompassing sexual function, both in terms of physical aspects and interpersonal relationships [14].

Although women in reproductive age are one of the main groups of health service users, studies on their health or functioning outside of the puerperalpregnancy cycle or outside of chronic diseases such as cancer are not very common [15].

Given these premises, this study aims to investigate the prevalence of sexual dysfunction and associated factors of women in reproductive age, as well as to evaluate the association between sexual dysfunction and the functioning of these women.

\section{Methods}

Design

A cross-sectional observational study was carried out between August 2015 and July 2016 in Primary Healthcare Units of the municipality of Santa Cruz, state of Rio Grande do Norte, Brazil. The study was approved by the Research Ethics Committee of the Federal University of Rio Grande do Norte and was conducted in accordance with the principles of the Declaration of Helsinki.

\section{Study participants}

For sample size calculation, a prevalence of $32.9 \%$ of sexual dysfunction in women in reproductive age [16], margin of error of $7 \%$, standard error of $5 \%$ and a replacement rate of $10 \%$ were considered, resulting in a sample with 191 women.

This study included 210 women aged between 19 and 49 years, with preserved cognition, who were not in the pregnancy-puerperal period and performed at least one sexual activity in the last 6 months, and who agreed to participate in the study signing an Informed Consent Form. Of this sample, 13 women were excluded because they did 
not complete the study protocol and 15 because they were in the climacteric period. The final sample consisted of 172 nonpregnant women with preserved ovarian function (presence of menstrual cycle) and sexually active.

The women were explained about the objectives of the study and the application of the questionnaires, as well as the need for them to be sincere in answering the questions. Moreover, they were instructed that they could withdraw their participation in the study anytime. When accepting to participate in the study, women were instructed to read the Informed Consent Form. The interviews always were conducted by women to minimize embarrassment during the application of questionnaires.

\section{Data collection}

Data were collected between February and July, 2016. We elaborated a study protocol with sociodemographic and obstetrical-gynecological questions about age, marital status, race, education, income, chronic diseases, menstrual cycle, dysmenorrhea, menarche age, bowel function, number and type of pregnancy, delivery type and the number of children.

We used the validated version of the Female Sexual Quotient (FSQ) questionnaire to evaluate the sexual function. FSQ is a useful tool in the investigation of female sexual activity. It has been specially developed and validated for the Brazilian population [17]. This questionnaire can be used for stratification of women in clinical or observational studies, since it evaluates the phases of sexual response cycle in general, by summing the scores of all questions, as well as considering domain-by-domain solely (desire and sexual interest, foreplay, personal arousal and getting along with the partner, comfort, orgasm and satisfaction) in 10 questions. FSQ is scored on a 100-point scale, with higher scores indicating greater sexual function and satisfaction [18]. The questionnaire showed good internal consistency in the studied sample (Cronbach alpha coefficient $=0.760$ ) .

We measured the functioning through the validated version for the Brazilian population of the World Health Organization Assessment Schedule 2.0 (WHODAS 2.0), a WHO instrument, which is a reliable and feasible tool for different cultures and adult populations and encompasses components of activities and participation of the International Classification of Functioning, Disability and Health (ICF) [19]. The instrument assesses, in 36 questions, the degree of difficulty in activities carried out in 6 domains of life (cognition, mobility, self-care, getting along with people, life activities, and participation in society) [20]. WHODAS 2.0 showed good internal consistency in the studied sample (Cronbach alpha coefficient $=0.910$ ).

\section{Data analysis}

We performed a statistical analysis on the Statistical Package for the Social Science SPSS ${ }^{\circledR}$ software version 20.0. Prevalence of sexual dysfunction was calculated, and bivariate analysis was used to estimate the association of independent variables with the outcome of sexual dysfunction by calculating the prevalence ratio, considering a 95\% Confidence Interval. Data were subjected to the Kolmogorov-Smirnov test to check normality. As data presented non-parametric distribution, the MannWhitney test was used to compare the mean values of the functional domains in the groups with and without sexual dysfunction. Statistical significance was considered when value $\mathrm{p} \leq 0.05$.

\section{Results}

The prevalence of sexual dysfunction in the studied population was $37.2 \%$. On the FSQ, out of 172 women, $39.5 \%$ scored regular or good, $25 \%$ unfavorable to regular, $23.3 \%$ good to excellent, $12.2 \%$ bad to unfavorable, and none considered their sexual health to be null or very poor.

Regarding the components of female sexual function, we observed that $26.2 \%$ of the women answered that they do not usually think of sex spontaneously, nor remember or imagine themselves during intercourse; $38.4 \%$ only think about having sexual intercourse sometimes; and $33.7 \%$ are willing to have sexual intercourse sometimes. Most women (51.2\%) showed that foreplay always encourages them to continue intercourse, $43.6 \%$ have lubrication during sexual intercourse, and $19.2 \%$ mentioned having dyspareunia sometimes. Regarding orgasm, $34.9 \%$ of the women reported reaching orgasm in all sexual intercourses, and 3.5\% never achieve orgasm, as shown in Table 1. 
Table 1 - Characteristics of sexual function according to Female Sexual Quotient (FSQ) ( $n=172)$

\begin{tabular}{lcccccc}
\hline & $\begin{array}{c}\text { Never } \mathbf{n} \\
\text { (\%) }\end{array}$ & $\begin{array}{c}\text { Rarely } \mathbf{n} \\
\text { (\%) }\end{array}$ & $\begin{array}{c}\text { Sometimes } \\
\mathbf{n}(\%)\end{array}$ & $\begin{array}{c}\sim \mathbf{5 0} \% \text { of } \\
\text { times } \mathbf{n}(\%)\end{array}$ & $\begin{array}{c}\text { Most times } \\
\mathbf{n}(\%)\end{array}$ & $\begin{array}{c}\text { Always } \\
\mathbf{n}(\%)\end{array}$ \\
\hline $\begin{array}{l}\text { 1. Do you often think of sex spontaneously, } \\
\text { remember sex, or imagine yourself having sex? }\end{array}$ & $45 \%(26.2)$ & $27(15.7)$ & $66(38.4)$ & $7(4.1)$ & $10(5.8)$ & $17(9.9)$ \\
$\begin{array}{l}\text { 2. Is your interest in sex enough for willing to } \\
\text { participate in sexual intercourse? }\end{array}$ & $12(7)$ & $15(8.7)$ & $58(33.7)$ & $11(6.4)$ & $27(15.7)$ & $49(28.5)$ \\
$\begin{array}{l}\text { 3. Do foreplay (caresses, kisses, hugs, cuddles, etc.) } \\
\text { encourage you to continue sexual intercourse? }\end{array}$ & $7(4.1)$ & $9(5.2)$ & $34(19.8)$ & $9(5.2)$ & $25(14.5)$ & $88(51.2)$ \\
$\begin{array}{l}\text { 4. Do you usually get lubricated (wet) during } \\
\text { intercourse? }\end{array}$ & $8(4.7)$ & $9(5.2)$ & $38(22.1)$ & $14(8.1)$ & $28(16.3)$ & $75(43.6)$ \\
$\begin{array}{l}\text { 5. During intercourse, as your partner's arousal } \\
\text { increases, do you also feel more stimulated for sex? }\end{array}$ & $3(1.7)$ & $8(4.7)$ & $34(19.8)$ & $11(6.4)$ & $33(19.2)$ & $83(48.3)$ \\
$\begin{array}{l}\text { 6. During intercourse, do you relax your vagina } \\
\text { enough to facilitate penis penetration? }\end{array}$ & $8(4.7)$ & $15(8.7)$ & $24(14)$ & $14(8.1)$ & $30(17.4)$ & $81(47.1)$ \\
$\begin{array}{l}\text { 7. Do you usually feel pain during intercourse when } \\
\text { the penis enters your vagina? }\end{array}$ & $83(48.3)$ & $23(13.4)$ & $33(19.2)$ & $12(7)$ & $5(2.9)$ & $16(9.3)$ \\
$\begin{array}{l}\text { 8. Can you get involved, without being distracted } \\
\text { (without losing concentration), during intercourse? }\end{array}$ & $18(10.5)$ & $15(8.7)$ & $57(33.1)$ & $8(4.7)$ & $23(13.4)$ & $51(29.7)$ \\
$\begin{array}{l}\text { 9. Can you achieve orgasm (maximum pleasure) in } \\
\text { sexual intercourse? }\end{array}$ & $6(3.5)$ & $13(7.6)$ & $47(27.3)$ & $13(7.6)$ & $33(19.2)$ & $60(34.9)$ \\
$\begin{array}{l}\text { 10. Does the degree of satisfaction you have with } \\
\text { sexual intercourse make you want to have sex other } \\
\text { times, on other days? }\end{array}$ & $9(5.2)$ & $11(6.4)$ & $49(28.5)$ & $10(5.8)$ & $36(20.9)$ & $57(33.1)$ \\
\hline
\end{tabular}

Regarding the bivariate analysis, no health habits and conditions (Table 3), and statistically significant association was found gynecological and obstetric variables (Table 4) between sociodemographic variables (Table 2), with sexual dysfunction.

Table 2 - Association between sexual dysfunction and sociodemographic characteristics of women between 19 and 49 years old - Santa Cruz/RN - Brazil, 2017 ( $n=172)$

\begin{tabular}{lccc}
\hline & \multicolumn{2}{c}{ Sexual dysfunction } & \multirow{2}{*}{ PR (95\% Cl) } \\
\cline { 2 - 3 } Age & & No $\mathbf{n}(\%)$ & $0.86(0.38-1.92)$ \\
Young adult & $11(17.2)$ & $21(19.4)$ & \\
Adult & $53(82.8)$ & $87(80.6)$ & \\
Race & & & \\
White & $22(34.4)$ & $28(25.9)$ & $1.50(0.76-2.93)$ \\
Black & $7(10.9)$ & $13(12)$ & $0.90(0.34-2.38)$ \\
Brown & $35(54.7)$ & $67(62)$ & $0.73(0.34-2.38)$ \\
Marital status & & & $0.99(0.53-1.83)$ \\
$\quad$ No partner & $30(46.9)$ & $51(47.2)$ & \\
With partner & $34(53.1)$ & $57(52.8)$ & \\
\hline
\end{tabular}

(To be continued) 
Table 2 - Continuation

\begin{tabular}{|c|c|c|c|}
\hline & \multicolumn{2}{|c|}{ Sexual dysfunction } & \multirow{2}{*}{ PR $(95 \% \mathrm{Cl})$} \\
\hline & Yes n (\%) & No $n(\%)$ & \\
\hline Education & & & $1.17(0.62-2.15)$ \\
\hline Up to elementary school & $32(50)$ & $50(46.3)$ & \\
\hline High school or higher education & $32(50)$ & $58(53.7)$ & \\
\hline Income & & & $1.98(0.90-4.40)$ \\
\hline Minimum wage & $54(84.4)$ & $79(73.1)$ & \\
\hline 2 or more minimum wage rates & $10(15.6)$ & $29(26.9)$ & \\
\hline
\end{tabular}

Table 3 - Association between sexual dysfunction and habits and health conditions of women between 19 and 49 years old Santa Cruz/RN - Brazil, 2017 ( $n=172)$

\begin{tabular}{|c|c|c|c|}
\hline & & & \\
\hline & Yes n (\%) & No n (\%) & \\
\hline Chronic diseases & & & $1.05(0.53-2.07)$ \\
\hline Yes & 19 (29.7) & $31(28.7)$ & \\
\hline No & $45(70.3)$ & 77 (71.3) & \\
\hline Depression & & & $0.84(0.07-9.47)$ \\
\hline Yes & $1(1.6)$ & $2(1.9)$ & \\
\hline No & $63(98.4)$ & $106(98.1)$ & \\
\hline Diabetes & & & $2.33(0.50-10.78)$ \\
\hline Yes & $4(6.2)$ & $3(2.8)$ & \\
\hline No & $60(93.8)$ & 105 (97.2) & \\
\hline Chronic pain & & & $0.87(0.47-1.62)$ \\
\hline Yes & $34(53.1)$ & $61(56.5)$ & \\
\hline No & $30(46.9)$ & 47 (43.5) & \\
\hline Sedentary lifestyle & & & $0.81(0.35-1.87)$ \\
\hline Yes & $10(15.6)$ & $20(18.5)$ & \\
\hline No & $54(84.4)$ & 88 (81.5) & \\
\hline
\end{tabular}

Table 4 - Association between sexual dysfunction and gynecological-obstetric variables of women between 19 and 49 years old - Santa Cruz/RN - Brazil, 2017 ( $n=172)$

\begin{tabular}{|c|c|c|c|}
\hline & \multicolumn{2}{|c|}{ Sexual dysfunction } & \multirow{2}{*}{ PR (95\% Cl) } \\
\hline & Yes n (\%) & No n (\%) & \\
\hline Menstrual cycle & & & $1.23(0.57-2.64)$ \\
\hline Regular & $42(76.4)$ & $71(72.4)$ & \\
\hline Irregular & $13(23.6)$ & 27 (27.6) & \\
\hline Dysmenorrhea & & & $0.57(0.30-1.06)$ \\
\hline Yes & $29(45.3)$ & 64 (59.3) & \\
\hline No & $35(54.7)$ & $44(40.7)$ & \\
\hline Bowel function & & & $0.78(0.41-1.48)$ \\
\hline Normal & $39(60.9)$ & $25(39.1)$ & \\
\hline Constipation & $25(39.1)$ & $36(33.3)$ & \\
\hline Menarche age & & & $0.74(0.40-1.40)$ \\
\hline$\leq 12$ years & $25(39.1)$ & $50(46.3)$ & \\
\hline$\geq 13$ years & $39(60.9)$ & $58(53.7)$ & \\
\hline
\end{tabular}


Table 4 - Continuation

\begin{tabular}{|c|c|c|c|}
\hline & & & PP $105 \%$ \\
\hline & Yes n (\%) & No n (\%) & PR (95\% CI) \\
\hline Sexual life onset & & & $1.16(0.60-2.22)$ \\
\hline Adolescence & $43(67.2)$ & $69(63.9)$ & \\
\hline Adulthood & $21(32.8)$ & $39(36.1)$ & \\
\hline Children & & & $0.58(0.25-1.34)$ \\
\hline Yes & $51(79.7)$ & $94(87)$ & \\
\hline No & $13(20.3)$ & $14(13)$ & \\
\hline Number of pregnancies & & & $1.88(0.83-4.25)$ \\
\hline None & $14(21.9)$ & $14(13)$ & \\
\hline At least one & $50(78.1)$ & $94(87)$ & \\
\hline Number of deliveries & & & $2.05(0.92-4.60)$ \\
\hline Nulliparous & $15(23.4)$ & $14(13)$ & \\
\hline At least one & 49 (76.6) & $94(87)$ & \\
\hline Vaginal delivery & & & $1.29(0.67-2.50)$ \\
\hline Yes & $44(68.8)$ & $68(63)$ & \\
\hline No & 20 (31.2) & $40(37)$ & \\
\hline Episiotomy & & & $1.07(0.58-2.00)$ \\
\hline Yes & $29(45.3)$ & 47 (43.5) & \\
\hline No & $35(54.7)$ & $61(56.5)$ & \\
\hline Cesarean & & & $0.67(0.36-1.25)$ \\
\hline Yes & $34(53.1)$ & $68(63)$ & \\
\hline No & $30(46.9)$ & $40(37)$ & \\
\hline Twin pregnancy & & & $1.61(0.73-3.57)$ \\
\hline Yes & $14(21.9)$ & $16(14.8)$ & \\
\hline No & $50(78.1)$ & 92 (85.2) & \\
\hline
\end{tabular}

Regarding functioning, we observed that women with sexual dysfunction have more disability in the domain "getting along with people" $(p=0.016)$; however, no interference of dysfunction was observed in the other domains of WHODAS (household activities, school or work activities, self-care, cognition, mobility, and participation in society) (Table 5).

Table 5 - Association between sexual dysfunction and WHODAS 2.0 domains of women between 19 and 49 years old - Santa Cruz/RN - Brazil, $2017(\mathrm{n}=172)$

\begin{tabular}{|c|c|c|c|}
\hline & Sexua & iction & \\
\hline & Yes (Mean \pm SD) & No (Mean \pm SD) & $P$ value* \\
\hline Household activities & $17.5 \pm 24.75$ & $15 \pm 24.24$ & 0.394 \\
\hline School or work activities & $3.45 \pm 9.86$ & $5.88 \pm 16.19$ & 0.989 \\
\hline Self-care & $7.97 \pm 15.03$ & $3.80 \pm 9.24$ & 0.063 \\
\hline Cognition & $17.81 \pm 18.76$ & $20.28 \pm 17.15$ & 0.165 \\
\hline Mobility & $20.90 \pm 23.04$ & $16.20 \pm 19.41$ & 0.150 \\
\hline Participation in society & $21.29 \pm 20.96$ & $19.71 \pm 20.32$ & 0.646 \\
\hline Getting along with people & $14.19 \pm 13.82$ & $10.34 \pm 13.81$ & $0.016^{*}$ \\
\hline Score total & $17.68 \pm 15.54$ & $15.76 \pm 13.62$ & 0.592 \\
\hline
\end{tabular}

${ }^{\star} p \leq 0.05$ 


\section{Discussion}

This study sought to evaluate the occurrence of female sexual dysfunction and its associated factors. In this sense, data evidenced a $37.2 \%$ prevalence of sexual dysfunction. In addition to this high prevalence of sexuality impairment, most women were worried about desire and excitement.

The prevalence of sexual dysfunction verified in this study is similar to previous studies conducted in other municipalities in the Northeast of Brazil, such as the findings of a survey carried out in a family planning clinic with women between 20 and 39 years old, which found $36 \%$ sexual dysfunction [21], and another study with women in reproductive age (35 to 49 years), who found $32.9 \%$ of sexual dysfunction [16].

The satisfaction degree with sexual life similar to the reported by the women in our study, mostly regular to good, was also found in a study conducted in a municipality in the northeast region of Brazil with women in reproductive age [16], and in the southeastern region in a study with college students aged between 17 and 39 years [22]. This fact showed that the different regions of Brazil have similar results regarding sexual satisfaction.

Hypoactive sexual desire (HSD) is the most common disorder in women's sexual health $[23,24]$, and the data obtained in this study showed that only $19.8 \%$ of the women think more than half of the times about themselves during intercourse. Studies have shown that the occurrence of HSD increases as the relationship progresses, [23, 25] due to the decrease in the partner's interest or the need for other stimuli and fantasies to desire sexual intercourse [23]; however, no association were observed between having or not a partner $(\mathrm{PR}=0.99$, $95 \% \mathrm{CI}=0.53-1.83$ ), nor between the age (young adult or adult) ( $\mathrm{PR}=0.86,95 \% \mathrm{CI}=0.38-1.92)$ and sexual dysfunction in our study.

Dyspareunia, reported by $19.2 \%$ of the women participating in this study, is a sexual disorder, whose prevalence ranges from $23.1 \%$ [26] to $27.8 \%$ [27]. Thus, the prevalence found in our study is lower than that found in previous studies conducted in Brazil. The prevalence of women that reported never or rarely having orgasms was $3.5 \%$ and $7.6 \%$, respectively, which was different from the prevalence found in previous studies in Brazil, reporting from 6.21\% [27] to $18 \%$ [21] and $21 \%$ of orgasmic dysfunction [26].
In our study, this prevalence was lower than in previous studies. Characteristics of the sample studied, the type of trial performed, and the clinical definition used for each dysfunction can explain this variation. This study had a community sample, which tends to have a lower prevalence of these dysfunctions than clinical samples. Moreover, evaluating through questionnaires lacks diagnostic precision possibly due to the difficulty of interviewees in understanding the questions and also because the questionnaire cannot measure the extent to which those sexual symptoms are a source of interpersonal and psychological stress for each of the subjects [26].

Non-association of sexual dysfunction with gynecological and obstetric variables was also found in another Brazilian study with women in reproductive age and climacteric phase [16] unlike what has already been reported in literature, which shows that sexual function may be affected by psychological factors, physiological and hormonal changes, perineal traumas due to childbirth or surgeries, pelvic floor dysfunctions and the woman's own life cycle, e.g. menopause $[5,6,12,28]$.

Regarding sociodemographic variables, previous studies have found an association between age and sexual dysfunction, and no relationship between health habits and conditions with sexual dysfunctions $[16,23]$. According to the literature, the multiplicity of chronic diseases, as well as depression, generates cumulative effects on the quality of women's sexual life, reducing sexual desire and hindering arousal, lubrication, and orgasm [12, 29]. However, the association between health habits and health conditions and sexual dysfunction was not found in our study.

Human functioning is described as a complex interaction between body functions, activities and participation in society, modulated by contextual factors [14] and can be measured using the ICF and summarized assessment tools based on this classification. WHODAS 2.0 is one of these tools and it verifies the level of activity limitation and participation restriction in six domains of life (cognition, mobility, self-care, getting along with people, life activities and participation in society) $[20,30]$.

The WHODAS 2.0 was used for this study, and it was observed that women with sexual dysfunction have greater inability for interpersonal relationships activities $(p=0.016)$. In the WHODAS 2.0 domains, 
the "getting along with people" one is associated with the ICF chapter, which approaches interpersonal relationships and interactions, defined as the actions and behaviors necessary to establish basic and complex personal interactions in a contextual and socially appropriate manner [14].

In the literature, there are no other studies that evaluate the impact of sexual dysfunction in the functioning of women in reproductive age, which hampers the external discussion of this possible association. However, this association has a theoretical assumption because of the interpersonal component that involves it. Importantly, this WHODAS domain involves activities such as dealing with strangers, relating to close people, maintaining and making new friends, and engaging in sexual activity.

The simultaneous investigation of the independent and dependent variables in our study can be cited as a study limitation. In addition, the study uses a questionnaire that relies on heterosexual relationships to assess female sexual function, disregarding homosexual women, as well as other psychological and dysfunctional aspects associated with partners that may interfere with the phenomenon under investigation.

Moreover, uncontrolled confounding, a potential for recall, and social acceptability may be biased in this study. Another aspect is that we used a validated questionnaire to measure the sexual function, which is not the most used instrument. This fact may result in a lack of comparability with results to those of prior studies that have used other instruments.

\section{Conclusion}

This study showed a considerable prevalence of sexual dysfunction in women in reproductive age out the pregnancy-puerperal cycle. In addition, hypoactive sexual desire and dyspareunia were observed. Socio-demographic variables, gynecological-obstetric characteristics, health habits and conditions did not modify the risk of sexual dysfunction, showing that in the studied sample this phenomenon is complex and possibly multifactorial.

However, we observed that women with sexual dysfunction have a higher level of incapacity for issues related to interpersonal relationships, demonstrating that sexual dysfunction is associated with decreased functioning on the "getting along with people" domain of women in reproductive age. Thus, the relevance of investigations about female sexual function among women in reproductive age not in the pregnancy-puerperal cycle is emphasized. Further studies should seek to understand the biopsychosocial dynamics associated with this dysfunction, as well as to understand how this dysfunction interferes with the functioning of women.

\section{References}

1. Brasil. Ministério da Saúde. Política Nacional de Saúde Funcional: construindo mais saúde para a população. Brasília: Ministério da Saúde; 2011.

2. Brasil. Ministério da Saúde. Política Nacional de Atenção Integral à Saúde da Mulher: princípios e diretrizes. Brasília: Ministério da Saúde; 2011.

3. Stephenson KR, Meston CM. Why is impaired sexual function distressing to women? the primacy of pleasure in female sexual dysfunction. J Sex Med. 2015;12(3):728-37.

4. Morotti E, Persico N, Battaglia B, Fabbri R, Meriggiola MC, Venturoli S, et al. Body imaging and sexual behavior in lean women with polycystic ovary syndrome. J Sex Med. 2013;10(11):2752-60.

5. Behboodi Moghadam Z, Rezaei E, Khaleghi Yalegonbadi F, Montazeri A, Arzaqi SM, Tavakol Z, et al. The effect of sexual health education program on women sexual function in Iran. J Res Health Sci. 2015;15(2):124-8.

6. Mendonça CR, Silva TM, Arrudai JT, Garcia-Zapata MTA, Amaral WN. Função sexual feminina: aspectos normais e patológicos, prevalência no Brasil, diagnóstico e tratamento. Femina. 2012;40(4):195-202.

7. Thiel RRC, Dambros M, Palma PCR, Thiel M, Riccetto CLZ, Ramos MF. Tradução para português, adaptação cultural e validação do Female Sexual Function Index. Rev Bras Ginecol Obstet. 2008;30(10):504-10.

8. Rashidi S, Dashti F. Sexual behavior pattern and related factors in women with breast cancer in Iran. Glob J Health Sci. 2016;8(7):266-72 
9. Lewis RW, Fugl-Meyer K, Corona G, Hayes RD, Laumann EO, Moreira ED Jr, et al. Definitions/epidemiology/risk factors for sexual dysfunction. J Sex Med. 2010;7(4):1598-607.

10. McCabe MP, Sharlip ID, Atalla E, Balon R, Fisher AD, Laumann E, et al. Definitions of sexual dysfunctions in women and men: a consensus statement from the Fourth International Consultation on Sexual Medicine. J Sex Med. 2016;13(2):135-43.

11. Khajehei M, Doherty M, Tilley PJM. An update on sexual function and dysfunction in women. Arch Womens Ment Health. 2015;18(3):423-33.

12. Appa AA, Creasman J, Brown JS, Van Den Eeden SK, Thom DH, Subak LL, et al. The impact of multimorbidity on sexual function in middle-aged and older women: beyond the single disease perspective. J Sex Med. 2014;11(11):2744-55.

13. Castro SS, Castaneda L, Araújo ES, Buchalla CM. Aferição de funcionalidade em inquéritos de saúde no Brasil: discussão sobre instrumentos baseados na Classificação Internacional de Funcionalidade, Incapacidade e Saúde (CIF). Rev Bras Epidemiol. 2016;19(3):679-87.

14. World Health Organization. CIF: Classificação Internacional de Funcionalidade, Incapacidade e Saúde. São Paulo: Edusp; 2015.

15. Carlotto K, Cesar JA, Hackenhaar AA, Ribeiro PRP. Características reprodutivas e utilização de serviços preventivos em saúde por mulheres em idade fértil: resultados de dois estudos transversais de base populacional no extremo sul do Brasil. Cad Saude Publica. 2008;24(9):2054-62.

16. Cavalcanti IF, Farias PN, Ithamar L, Silva VM, Lemos A. Função sexual e fatores associados à disfunção sexual em mulheres no climatério. Rev Bras Ginecol Obstet. 2014;36(11):497-502.

17. Abdo CHN. Elaboração e validação do quociente sexual - versão feminina: uma escala para avaliar a função sexual da mulher. Rev Bras Med. 2006;63(9):477-82.
18. Abdo CHN. Quociente sexual feminino: um questionário brasileiro para avaliar a atividade sexual da mulher. Diagn Tratamento. 2009;14(2):89-91.

19. Silveira C, Parpinelli MA, Pacagnella RC, Andreucci CB, Angelini CR, Ferreira EC, et al. Validation of the 36-item version of the WHO Disability Assessment Schedule 2.0 (WHODAS 2.0) for assessing women' s disability and functioning associated with maternal morbidity. Rev Bras Ginecol Obstet. 2017;39(2):44-52.

20. Silveira C, Parpinelli MA, Pacagnella RC, Camargo RS, Costa ML, Zanardi DM, et al. Adaptação transcultural da escala de avaliação de incapacidades da Organização Mundial de Saúde (WHODAS 2.0) para o português. Rev Assoc Med Bras. 2013;59(3):234-40.

21. Ferreira ALCG, Souza AI, Amorim MMR. Prevalência das disfunções sexuais femininas em clínica de planejamento familiar de um hospital escola no Recife, Pernambuco. Rev Bras Saude Matern Infant. 2007;7(2):143-50.

22. Fonseca SF, Blank VLG, Barros MVG, Nahas MV. Percepção de saúde e fatores associados em industriários de Santa Catarina, Brasil. Cad Saude Publica. 2008;24(3):567-76.

23. Lara LAS, Silva ACJSR, Romão APMS, Junqueira FRR. Abordagem das disfunções sexuais femininas. Rev Bras Ginecol Obstet. 2008;30(6):312-21.

24. Kingsberg S, Woodard T. Disfunción sexual femenina: con enfoque en la disminución del deseo. Obstet Gynecol. 2015;125:477-86.

25. Nappi RE, Cucinella L, Martella S, Rossi M, Tiranini L, Martini E. Female sexual dysfunction (FSD): prevalence and impact on quality of life (QoL). Maturitas. 2016;94:87-91.

26. Abdo CH, Oliveira WM Jr, Moreira ED Jr, Fittipaldi JA. Prevalence of sexual dysfunctions and correlated conditions in a sample of brazilian women-results of the Brazilian study on sexual behavior (BSSB). Int J Impot Res. 2004;16(2):160-6. 
27. Fonseca MFSM, Beresin R. Avaliação da função sexual de estudantes de graduação em enfermagem. Mundo Saude Sao Paulo. 2008;32(4):430-6.

28. Handelzalts JE, Yaakobi T, Levy S, Peled Y, Wiznitzer A, Krissi H. The impact of genital self-image on sexual function in women with pelvic floor disorders. Eur J Obstet Gynecol Reprod Biol. 2017;211:164-8.

29. Polland AR, Davis M, Zeymo A, Iglesia CB. Association between comorbidities and female sexual dysfunction: findings from the third National Survey of Sexual Attitudes and Lifestyles (Natsal-3). Int Urogynecol J. 2019;30(3):377-83.
30. Silveira C, Souza RT, Costa ML, Parpinelli MA, Pacagnella RC, Ferreira EC, et al. Validation of the WHO Dis ability Assessment Schedule (WHODAS 2.0) 12-item tool against the 36-item version for measuring functioning and disability associated with pregnancy and history of severe maternal morbidity. Int J Gynaecol Obstet. 2018;141(1):39-47.

Received in 10/11/2018

Recebido em 11/10/2018

Recibido en $11 / 10 / 2018$

Approved in 07/01/2020

Aprovado em 07/01/2020

Aprobado en 07/01/2020 